\title{
EFEKTIFITAS PENGGUNAAN CHITOSAN SEBAGAI AGEN ANTIMIKROBA PADA DAGING AYAM BROILER
}

\author{
Rahayu, L. ${ }^{1 *}$, V. P. Bintoro ${ }^{2}$, dan Nurwantoro ${ }^{2}$ \\ Dosen Jurusan Biologi IKIP PGRI, Semarang dan Dosen Magister Ilmu Ternak \\ Universtitas Diponegoro, Semarang \\ *E-mail : R.Linda@live.co.uk
}

\begin{abstract}
ABSTRAK
Penelitian penggunaan chitosan dengan konsentrasi yang berbeda sebagai larutan perendaman daging ayam broiler selama 5 menit serta penyimpanan 8 jam telah dilakukan untuk mengetahui pengaruhnya terhadap total mikroba dan nilai TVBN. Hasil penelitian menunjukkan bahwa perendaman daging ayam dalam larutan chitosan dengan konsentrasi yang berbeda berpengaruh nyata $(P<0,05)$ terhadap total mikroba, dan tidak berpengaruh terhadap nilai TVBN. Setelah penyimpanan 8 jam daya hambat total mikroba yang paling tinggi yaitu konsentrasi $2 \%$ sebesar $4,4 \times 10^{6} \mathrm{CFU} / \mathrm{g}$.
\end{abstract}

Kata kunci: Chitosan, total mikroba, TVBN, daging ayam broiler

\section{Pendahuluan}

Daging ayam broiler merupakan bahan pangan yang penting dalam pemenuhan kebutuhan zat gizi. Nilai gizi daging ayam terletak pada protein daging yang mengandung beberapa asam asam amino essensial yang lengkap. Daging ayam broiler mengandung asam amino essensial yang tinggi terutama arginin, sistin dan fenilalanin yang sangat diperlukan oleh tubuh manusia (Mountney, 1989). Komponen kimia daging ayam selain protein adalah lemak, air, karbohidrat dan mineral. Menurut Forest at al., (1975) kandungan daging ayam terdiri dari protein $16-22 \%$, lemak $1,5-13 \%$ senyawa non protein nitrogen $1 \%$, karbohidrat $0,5 \%$ dan kadar air $65-80 \%$. Berdasarkan kandungan air dan nutriennya yang tinggi, daging mudah mengalami kerusakan, hal ini dikarenakan daging merupakan media yang baik untuk berkembangnya mikroba, dan sulit sekali dalam menghindari cemaran mikroba sejak dipanen, sehingga daging termasuk dalam kelompok perishable food. Mikroba yang mengkontaminasi daging, khususnya bakteri patogen dapat menyebabkan foodborne disease. Lebih dari $90 \%$ foodborne disease disebabkan oleh kontaminasi mikroba patogen. Selain menimbulkan penyakit, mikroba merupakan faktor utama penyebab menurunnya kualitas dan kerusakan karkas sehingga masa simpan daging ayam menjadi pendek. Oleh karena itu diperlukan alternatif bahan yang aman dan mudah diaplikasikan untuk menghambat pertumbuhan mikroba sehingga dapat mempertahankan kualitas dan memperpanjang masa simpan produk. Salah satunya adalah dengan penggunaan chitosan.

Chitosan ( $\beta$-1,4 amino-2-dioksi-D-glukosa) merupakan biopolimer karbohidrat yang diperoleh dari proses deasetilasi chitin, yakni produk samping (limbah) dari pengolahan industri perikanan, khususnya dari cangkang crustacea seperti udang dan rajungan. Chitosan dapat terdegradasi secara biologis karena sifatnya alami, tidak beracun. Dari hasil beberapa penelitian, chitosan memperlihatkan kemampuannya dalam melawan mikroba perusak dan patogen (Rabea et al., 2003). Chitosan digunakan sebagai preservasi pada daging sapi, dan mampu menghambat pertumbuhan bakteri perusak seperti Bacillus subtillis IFO 3025, Escherichia coli, Pseudomonas fragi IFO 3458 pada konsentrasi 0,1 sampai 1\% (Darmaji dan Izumimoto, 1994). Chitosan pada konsentrasi 2\% mampu menghambat pertumbuhan Listeria monocytogenes pada steak daging babi (Ye et al., 2007), menghambat pertumbuhan mikroba pada daging babi panggang (Yingyuad et al., 2006). Chitosan pada konsentrasi 0,1 sampai $1 \%$ dapat menghambat pertumbuhan Aspergillus niger (Sebti et al., 2005), juga dapat menghambat pertumbuhan spora Clostridium perfringens pada daging sapi dan kalkun yang digiling dengan konsentrasi 3\% (Juneja et al., 2006).

Penelitian ini bertujuan untuk mengetahui efektivitas chitosan dalam menghambat pertumbuhan total mikroba dan terhadap angka TVBN. Manfaat penelitian ini adalah memberikan informasi ilmiah mengenai seberapa efektif penggunaan chitosan dalam menghambat pertumbuhan mikroba dan pengaruhnya terhadap angka TVBN.

\section{Materi dan Metode Penelitian \\ Materi yang digunakan dalam penelitian adalah ayam broiler sebanyak 28 ekor. Ayam tersebut dipilih berdasarkan umur yang sama dengan bobot berkisar 1,5-1,7 kg dengan. Daging yang diambil adalah bagian Pectoralis superficialis.}


Chitosan diperoleh dari PT. Araminta Sidhakarya, Tanggerang dengan Derajat Deasetilasi $>80 \%$. Asam asetat $1 \%$ digunakan sebagai pelarut chitosan.

\section{Metode Pengukuran total mikroba}

Metode penghitungan jumlah total mikroba yang digunakan adalah metode Standard Plate Count (SPC) yaitu metode perhitungan jumlah mikroba yang hidup dan berkembang biak dengan media Plate Count Agar (PCA) (Fardiaz, 1993). Prosedurnya Satu ml sampel yang telah diblender (penenceran pertama) dimasukan dalam $9 \mathrm{ml}$ aquades sebagai pengenceran $10^{-2}$. Pengenceran diulang sampai didapat pengenceran $10^{-6}$. Sebanyak $1 \mathrm{ml}$ sampel dari hasil masing-masing pengenceran tersebut, kemudian dituangkan dalam cawan petri steril (pour plate). Media PCA dituangkan kedalam cawan petri yang berisi sampel dan cawan digerakgerakan di atas meja. Cawan diinkubasi dalam posisi terbalik pada suhu $37^{\circ} \mathrm{C}$ selama 24 jam, kemudian dilakukan penghitungan jumlah mikroba dengan colony counter (CFU/g). Penghitungan jumlah koloni dan faktor pengencerannya sebagai berikut:

Jumlah koloni per gram $=$ jumlah koloni percawan $\mathrm{x}$ $1 /$ faktor pengenceran.

Faktor Pengenceran = pengenceran $\mathrm{x}$ volume yang diencerkan.

\section{Metode pengukuran nilai TVBN}

Sampel sebanyak 25 gram diblender selama 1 menit bersama larutan $7 \%$ asam trikloroasetat sebanyak $75 \mathrm{ml}$. Larutan kemudian disaring. Sebanyak $1 \mathrm{ml}$ filtrat yang diperoleh dimasukkan dalam outher chamber cawan conway. Larutan asam borat sebanyak $1 \mathrm{ml}$ dimasukkan dalam inner chamber conway dalam posisi hampir menutup kemudian $1 \mathrm{ml} \mathrm{K2CO3}$ jenuh ditambahkan kedalam outher chamber, setelah itu segera cawan conway ditutup. Disamping itu blanko total dibuat dengan cara mengganti sampel dengan $5 \%$ Asam trikloroasetat dan langkah selanjutnya seperti prosedur diatas. Cawan conway digoyang perlahanlahan, selanjutnya cawan diinkubasi pada suhu kamar selama semalam. Setelah inkubasi selesai, larutan asam borat dalam inner chamber cawan conway blanko dititrasi dengan larutan 1/70 N HCl hingga larutan asam borat berubah menjadi warna merah muda. Kemudian larutan asam borat pada cawan conway sampel juga dititrasi sampai diperoleh warna muda yang sama dengan warna merah muda pada cawan conway blanko.

Rumus penghitungan TVBN (mg/100g):

(ml titrasi sampel-ml titrasi blanko) x $80 \mathrm{mg} \mathrm{N}$ (Nitrogen) (Santoso, 1999)

Rancangan percobaan yang digunakan dalam penelitian ini adalah Rancangan Acak Lengkap (RAL) dengan 7 perlakuan dan 3 ulangan. Setiap perlakuan yaitu daging ayam direndam dalam larutan chitosan dengan konsentrasi yang berbeda-beda selama 5 menit kemudian disimpan selama 8 jam pada suhu ruang sebagai berikut.

$$
\begin{gathered}
\mathrm{T}_{0}=\begin{array}{c}
\text { Daging ayam direndam dalam larutan } \\
\text { aquades. }
\end{array} \\
\mathrm{T}_{1}=\begin{array}{c}
\text { Daging ayam direndam dalam larutan } \\
\text { chitosan } 0,5 \% .
\end{array} \\
\mathrm{T}_{2}=\begin{array}{c}
\text { Daging ayam direndam dalam larutan } \\
\text { chitosan } 1 \% .
\end{array} \\
\mathrm{T}_{3}=\begin{array}{c}
\text { Daging ayam direndam dalam larutan } \\
\text { chitosan } 1,5 \% .
\end{array} \\
\mathrm{T}_{4}=\begin{array}{c}
\text { Daging ayam direndam dalam larutan } \\
\text { chitosan } 2 \% .
\end{array} \\
\mathrm{T}_{5}=\begin{array}{c}
\text { Daging ayam direndam dalam larutan } \\
\text { chitosan } 2,5 \% .
\end{array} \\
\mathrm{T}_{6}=\begin{array}{c}
\text { Daging ayam direndam dalam larutan } \\
\text { chitosan } 3 \% .
\end{array}
\end{gathered}
$$

\section{Hasil dan Pembahasan}

Berdasarkan data yang terlihat pada Tabel 1, dapat diketahui bahwa perendaman daging ayam pada larutan chitosan dapat menghambat pertumbuhan mikroba. Hasil analisis variansi menunjukkan chitosan berpengaruh nyata $(\mathrm{P}<0,05)$ menurunkan total mikroba daging ayam broiler. Proses penghambatan pertumbuhan mikroba berkaitan dengan karakteristik chitosan sebagai agen antimikroba (Rabea et al., 2003). Kemampuan chitosan sebagai agen antimikroba juga berkaitan dengan kemampuannya melapisi bahan, mengikat air daging dan memiliki gugus amino yang reaktif serta berfungsi sebagai chelating agent yang secara selektif mengikat mineral misalnya zat besi sehingga menghambat pertumbuhan dan mencegah produksi toksin oleh mikroba (No et al., 2002). 
Tabel 1 . Rerata Total Mikroba dan Nilai TVBN Daging Ayam yang Direndam dalam Larutan Chitosan dengan Konsentrasi yang Berbeda setelah Penyimpanan 8 Jam pada Suhu Ruang.

\begin{tabular}{cccc}
\hline \hline Perlakuan & Konsentrasi & $\begin{array}{c}\text { Rerata Total } \\
\text { Mikroba }\end{array}$ & $\begin{array}{c}\text { Rerata } \\
\text { TVBN }\end{array}$ \\
\hline T0 & $\%$ & CFU/g & $\mathrm{mg} \mathrm{N} / 100 \mathrm{~g}$ \\
T1 & 0 & $1.2 \times 107$ & 13.33 \\
T2 & 0,5 & $9.8 \times 106$ & 12.98 \\
T3 & 1 & $9.4 \times 106$ & 12.78 \\
T4 & 1,5 & $8.1 \times 106$ & 12.49 \\
T5 & 2 & $4.4 \times 106$ & 12.48 \\
T6 & 2,5 & $5.2 \times 106$ & 12.55 \\
& 3 & $4.9 \times 106$ & 12.45 \\
\hline
\end{tabular}

Mekanisme utama chitosan dalam menghambat pertumbuhan mikroba adalah chitosan mempunyai gugus amino positif yang mampu mengikat gugus karboksilat negatif yang berada dipermukaan sel bakteri (Rabea et al., 2003 ). Beberapa ikatan elektrokimia dapat mengubah distribusi muatan positif dan negatif pada permukaan membran sel, sehingga menyebabkan pelemahan atau kerusakan membran diikuti komponen sel mikroba (Juneja et al., 2006). Mekanisme ini didukung oleh studi dengan mikroskop elektron yang menunjukkan bahwa polimer berikatan dan memperlemah membran terluar bakteri (Helender et al., 2001 yang disitasi Juneja et al., 2006), sama seperti studi dengan mikroskop atomic force yang menunjukkan bahwa nanopartikel chitosan dapat menyebabkan kerusakan membran sel dan kebocoran sitoplasma organisme Salmonella chloraesius (Qi et al., 2004 yang disitasi Juneja et al., 2006).

Berdasarkan Tabel 1 dapat diketahui bahwa daya hambat chitosan paling tinggi pada perlakuan T4, setelah itu aktivitas penghambatannya menurun kembali. Hasil penelitian ini sama seperti yang dilakukan oleh Yudiantoro et al. (2007) yang menunjukkan, bahwa semua aktivitas antibakteri chitosan semakin menurun seiring peningkatan konsentrasi chitosan. Menurut Yudiantoro et al. (2007) penghambatan yang lebih tinggi pada chitosan konsentrasi rendah, diduga karena viskositas larutan yang lebih rendah.

\section{Total Volatil Base Nitrogen (TVBN)}

TVBN digunakan sebagai indeks dekomposisi daging. Pengamatan TVBN bertujuan untuk mengetahui aktivitas antimikrobia dari chitosan dalam menghambat aktivitas antimikrobia pengurai protein, sehingga terbentuknya senyawasenyawa volatil (amoniak, metil amin sederhana, dimetil amin). Hasil analisis variansi menunjukkan bahwa perendaman daging ayam dalam larutan chitosan tidak berpengaruh terhadap nilai TVBN tetapi secara umum nilai rerata TVBN mengalami penurunan dibandingkan dengan kontrol seperti yang tersaji pada Tabel 1 .
Penurunan nilai TVBN dalam penelitian ini menunjukkan hasil yang sama dengan penelitian Darmadji dan Izumimoto (1994) pada daging sapi yang dicelupkan dalam larutan chitosan. Menurunnya angka TVBN menunjukkan chitosan mampu menghambat aktivitas mikroba sehingga mengurangi proses penguraian protein menjadi amoniak, metilamin sederhana, dimetil amin, trietilamin, komponen sulfur volatil (Santoso, 1999).

\section{Kesimpulan}

Berdasarkan pengujian mikrobiologis, penggunaan chitosan sebagai larutan perendaman pada daging ayam broiler selama 5 menit dan dilanjutkan dengan penyimpanan 8 jam pada suhu ruang efektif dalam menghambat peertumbuhan total mikroba, dalam penelitian ini daya hambat yang paling tinggi adalah konsentrasi 2\%. Sedangkan perendaman chitosan pada daging ayam tidak menunjukan pengaruh nyata terhadap angka TVBN.

\section{DAFTAR PUSTAKA}

Darmadji, P. and M. Izumimoto. 1994. Effect of chitosan in meat preservation. Meat Sci. 38: $243-254$.

Fardiaz, S. 1993. Analisis Mikrobiologi Pangan. PT. Raja Gradindo Persada, Jakarta.

Juneja, V.K., H. Thippareddi, L. Bari, Y. Inatsu, S. Kawamoto, and M. Friedman. 2006. Chitosan protects cooked ground beef and turkey against Clostridium perfringens spores during chilling. Food Sci. 71:236-240.

No, H.K., N.Y.Park, S.H. Lee, and S.P. Meyers. 2002. Antimicrobial characteristics of chitosan and chitosan oligomers with different molecular weights. J. Food Microbiol.74:6572.

Rabea, E.I., M.E. Badawy., C.V. Steven., G. Smagghe., and W Steurbaut. 2003. Chitosan as antimicrobial agent: applicationsnad mode of action. Biomacromolecules. 4: 1457-1465.

Santoso, U. 1999. Hand Out Hasil Pertanian Pokok Bahasan Metode Analisis Hasil-hasil 
Perikanan. Yogyakarta : Fakultas Teknologi Pertanian UGM.

Sebti, I., A. Martial-Gros., A. Carnet-Pantiez., S. Grelier and V. Coma. 2005. Chitosan polymer as bioactive coating and film against Aspergillus niger contamination. J. Food Sci. 70: M100-M104.

Soeparno. 1998. Ilmu dan Teknologi Daging. Gadjah Mada Unyversity Press. Yogyakarta.

Stell, R. G. D., dan J.H. Torrie. 1995. Prinsip dan Prosedur Statistika. Edisi ke 4. Penerbit Gramedia Pustaka Utama, Jakarta. (Diterjemahkan oleh B. Sumantri).

Ye, M., H. Neeto. and H. Chen. 2007. Control of Listeria monocytogenes on ham steaks by antimicrobials incorporated into chitosan coated plastic film. Food Microbiol. 25: 260268.

Yingyuad, S., S. Ruamsin., D. Reekprkhon., S. Douglas., S Pongampai., and U. Siripatrawan. 2006. Effect of chitosan coating and vacum packaging on the quality of refrigerated grilled pork. Packag. Technol. Sci. 19:149157

Yudiantoro, S. Rizal dan F. Nurainy. 2007. Uji Aktivitas Kitosan Sebagai Antibakteri Terhadap Bakteri Patogen dan Perusak Makanan dengan Metode Sumur. Fakultas Pertanian, Universitas Lampung. 